\title{
Overexpression of Toll-like receptor 4 contributes to the internalization and elimination of Escherichia coli in sheep by enhancing caveolae-dependent endocytosis
}

Yao Li ${ }^{1}$, Yue Zhao ${ }^{1}$, Xueling X ${ }^{1}$, Rui Zhang ${ }^{1}$, Jinlong Zhang ${ }^{2}$, Xiaosheng Zhang ${ }^{2}$, Yan $\mathrm{Li}^{1,3^{*}}$, Shoulong Deng ${ }^{4^{*}}$ and Zhengxing $\operatorname{Lian}^{1 *}$ (D)

\begin{abstract}
Background: Gram-negative bacterial infections have a major economic impact on both the livestock industry and public health. Toll-like receptor 4 (TLR4) plays a crucial role in host defence against Gram-negative bacteria. Exploring the defence mechanism regulated by TLR4 may provide new targets for treatment of inflammation and control of bacterial infections. In a previous study, we generated transgenic sheep overexpressing TLR4 by microinjection to improve disease resistance. The defence mechanism through which TLR4 overexpression protected these sheep against pathogens is still not fully understood.
\end{abstract}

Results: In the present study, we used Escherichia coli to infect monocytes isolated from peripheral blood of the animal model. The overexpression of TLR4 strongly enhanced the percentage of endocytosis and capacity of elimination in monocytes during the early stages of infection. This phenomenon was mainly due to overexpression of TLR4 promoting caveolae-mediated endocytosis. Pretreatment of the transgenic sheep monocytes with inhibitors of TLR4, Src signalling, or the caveolae-mediated endocytosis pathway reduced the internalization of bacteria, weakened the ability of the monocytes to eliminate the bacteria, and increased the $\mathrm{pH}$ of the endosomes.

\footnotetext{
*Correspondence: scauly@cau.edu.cn; popo84350746@163.com; lianzhx@cau.edu.cn

'Beijing Key Laboratory for Animal Genetic Improvement, National Engineering Laboratory for Animal Breeding, Key Laboratory of Animal Genetics and Breeding of the Ministry of Agriculture, College of Animal Science and Technology, China Agricultural University, Beijing, China ${ }^{4}$ Institute of Laboratory Animal Sciences, Chinese Academy of Medical Sciences and Comparative Medicine Center, Peking Union Medical College, Beijing, China

Full list of author information is available at the end of the article
}

(c) The Author(s). 2021 Open Access This article is licensed under a Creative Commons Attribution 4.0 International License, which permits use, sharing, adaptation, distribution and reproduction in any medium or format, as long as you give appropriate credit to the original author(s) and the source, provide a link to the Creative Commons licence, and indicate if changes were made. The images or other third party material in this article are included in the article's Creative Commons licence, unless indicated otherwise in a credit line to the material. If material is not included in the article's Creative Commons licence and your intended use is not permitted by statutory regulation or exceeds the permitted use, you will need to obtain permission directly from the copyright holder. To view a copy of this licence, visit http://creativecommons.org/licenses/by/4.0/. The Creative Commons Public Domain Dedication waiver (http://creativecommons.org/publicdomain/zero/1.0/) applies to the data made available in this article, unless otherwise stated in a credit line to the data. 
(Continued from previous page)

Conclusion: Together, our results reveal the effects of TLR4 on the control of E. coli infection in the innate immunity of sheep and provide crucial evidence of the caveolae-mediated endocytosis pathway required for host resistance to invading bacteria in a large animal model, providing theoretical support for breeding disease resistance in the future. Furthermore, Src and caveolin 1 (CAV1) could be potentially valuable targets for the control of infectious diseases.

Keywords: Caveolae-dependent endocytosis, Host defence infection, Inflammatory responses, Monocytes, Toll-like receptor 4

\section{Background}

Toll-like receptor 4 (TLR4) is known to be a patternrecognition receptor that triggers innate immunity [1-3]. This molecule is expressed mainly in the immunocytes of mammals, including macrophages, monocytes, neutrophils, and dendritic cells [4]. As an important component of the body's defence system, monocytes not only promote specific proinflammatory and anti-inflammatory processes but also endocytose and eliminate pathogens to maintain cell homeostasis [5]. TLR4 recognizes Gram-negative bacteria via their signature molecules to activate the host's innate immune response, which is tightly regulated via distinct factors and pathways. The localization of TLR4 has emerged as a key determinant of TLR4 function. These factors include subcellular TLR4 localization and ligand sensing, which occurs on the cell surface through activation of the Toll-interleukin 1 receptor (TIR) domain containing adaptor protein (TIRAP)-myeloid differentiation factor 88 (MyD88)-dependent pathway and through endocytosis that activates the TRIF-related adaptor molecule (TRAM)-TIR domain containing adaptor-inducing interferon- $\beta$ (TRIF)-dependent pathway [6]. TLR4 does not simultaneously activate the MyD88- and TRIFdependent pathways; instead, it induces these two signalling pathways sequentially following the endocytosis of pathogens [7]. First, when bacteria bind to TLR4-bound myeloid differentiation protein 2 (MD2) on the plasma membrane, TIRAP and MyD88 participate in the rapid activation of the TIRAP-MyD88-dependent pathway, which results in the production of proinflammatory cytokines [8]. Next, TLR4 enters the endocytosis pathway by being translocated away from the cell surface to the endosome accompanied by cargo [9]. With the help of the bridging factor TRAM, TLR4 recruits the TRIF receptor that drives the TRAM-TRIF-dependent pathway and leads to the production of type I interferons [10].

The endocytosis of pathogens has emerged as a critical control step in the antimicrobial signal transduction process [11]. Macrophages with defects in the internalization of cell surface TLR4 exhibit enhanced inflammatory cytokine production following stimulation with lipopolysaccharide (LPS) and fail to induce LPS tolerance despite repeated LPS stimulation [12]. The internalization of TLR4 into the endosome is one of the negative regulatory mechanisms that prevent an excessive inflammatory response [13].

After immunocytes internalize invading pathogens by endocytosis, a series of vesicular trafficking steps occur with organelles ranging from early endosomes to lysosomes. At the end of this process, the cargo can be effectively degraded when mature endosomes fuse with endolysosomes [14]. Acidification is essential during endosome maturation: a sufficiently low $\mathrm{pH}$ is a prerequisite for endosome-lysosome fusion and provides optimal conditions for the activity of certain hydrolytic enzymes [15]. TLR4 is reported to control the rhythm of endosomal maturation and to guide bacteria into the "fast lane" of antigen presentation compared to apoptotic cell (not involved in TLR4) degradation by phagocytes. The inhibition of TLR4 downstream signalling events, such as mitogen-activated protein kinase (MAPK), blocks this enhanced endosomal maturation [16]. Research on Salmonella has found that TLR4 signalling enhances the acidification rate of endosomes containing Salmonella [17]. However, the mechanisms linking TLR4 and endosome maturation remain to be fully explored.

Endocytosis occurs via a variety of mechanisms in mammalian cells, including clathrin-dependent endocytosis, micropinocytosis, phagocytosis, and caveolae-dependent endocytosis $[18,19]$. Caveolae are submicroscopic plasma membrane lipid rafts that are rich in cholesterol and sphingolipids and found in many mammalian cell types [20]. Caveolae have vital functions in signal transduction and the elimination of bacteria [21]. TLR4 activation has been associated with the translocation of TLR4 and signalling proteins into caveolae since the inhibition of the caveolae-dependent endocytosis pathway blocks LPSinduced TLR4 signalling [22]. Caveolin 1 (CAV1) is the principal structural and signalling component of caveolae and has been used as a marker protein [23]. This molecule has been shown to be involved in endocytosis. The findings from a mouse model of sepsis indicated that CAV1 is an important protective modulator of sepsis, as CAV1 may regulate inflammation and reduce the bacterial burden [24]. Studies on mouse macrophages found that knocking out $C A V 1$ reduces their capacity for endocytosis and their ability to kill bacteria. In addition, the expression of TLR4 and MyD88 was decreased, and the production 
of inflammatory cytokines was also decreased [25]. Several studies have found that CAV1 can be phosphorylated by the tyrosine kinase Src, and activated CAV1 promotes caveolae-mediated endocytosis [21, 26]. Furthermore, the Src kinase family phosphorylates TLR4 to dissociate MyD88 and MyD88 adapter-like (MAL)/TIRAP, thereby suppressing LPS-induced inflammatory responses [27]. These results indicate the potential role of TLR4 in caveolae-dependent endocytosis and signalling, although the precise mechanisms remain unknown.

In our previous study, we bred transgenic sheep overexpressing TLR4 $[28,29]$. These transgenic sheep produced a stronger inflammatory response during the early stages of bacterial infection than control sheep, and the infection subsided quickly. TLR4 is known to increase the expression of scavenger receptors, which enhance the adhesion capacity of immunocytes and contribute to the endocytosis of pathogenic bacteria [30, 31]. However, the effect of TLR4 overexpression on immune defence mechanisms has not been completely elucidated. Here, we continued this line of investigation by determining the effects of TLR4 on bacterial endocytosis and the bactericidal ability. We further examined whether the immunocytes of transgenic sheep have improved antibacterial ability via caveolae-dependent endocytosis.

\section{Methods}

\section{Sheep}

The founder transgenic sheep were produced through microinjection of a linear vector containing sheep TLR4 (Fig. 1a) into the pronucleus of fertilized eggs [28, 29]. Founder transgenic sheep were bred with wild-type sheep. Among the offspring of the transgenic sheep, healthy male 2- to 3-year-old sheep were identified as either wild-type or transgenic by Southern blotting. Genomic DNA (20 $\mu \mathrm{g})$ was extracted from the ear tissue and digested with HindIII (New England Biolabs, Ipswich, Britain). The probe used for Southern blotting was generated by PCR with the following primer pair: forward (F), 5'-ACTGGTAAAG AACTTGGAGGAGG-3' and reverse (R), 5'-CCTTCA CAGCATTCAACAGACC-3', and the 671-bp PCR product was labelled with digoxigenin (Roche Diagnostics, Mannheim, Germany). Four sheep were included in the transgenic and four sheep in wild-type groups for the subsequent experiments.

\section{Cells and culture conditions}

The initial peripheral blood mononuclear cells were isolated from the peripheral blood of sheep that had been collected aseptically from the jugular vein in separation medium (TBDscience, Tianjing, China), followed by density gradient centrifugation $(2,000 \times g$ for $30 \mathrm{~min})$. The cells were seeded at a density of $1 \times 10^{6}$ cells per well in 6-well culture plates. After incubation at $37^{\circ} \mathrm{C}$ in a $5 \%$
$\mathrm{CO}_{2}$ incubator for $2 \mathrm{~h}$, the nonadherent cells were removed by washing the wells three times with phosphatebuffered saline (PBS). The adherent cells were cultured at $37^{\circ} \mathrm{C}$ in a $5 \% \quad \mathrm{CO}_{2}$ incubator with RPMI-1640 medium (Gibco, Grand Island, NY, USA) containing $10 \%$ foetal bovine serum (FBS; Gibco). After a further $48 \mathrm{~h}$ of incubation and the removal of nonadherent cells, the adherent cells were mainly composed of monocytes.

\section{Immunofluorescence assay}

First, the monocytes were washed with PBS and then digested with $0.25 \%$ trypsin-EDTA (Gibco, Grand Island, $\mathrm{NY}$, USA) at $37^{\circ} \mathrm{C}$ for $5-10 \mathrm{~min}$. After termination of the digestion, the cell suspension was poured into a $15 \mathrm{~mL}$ centrifuge tube and washed twice with PBS, RPMI-1640 medium was added, and a cell counting plate was used for counting. Monocytes were seeded on 8-well glass chamber slides (Millipore, Massachusetts, USA) at a density of $1 \times 10^{5}$ cells per well. After $12 \mathrm{~h}$, the cells were washed three times with PBS before being fixed with 4\% paraformaldehyde for $20 \mathrm{~min}$, followed by blocking with Immunol Staining Blocking Buffer (Beyotime, Beijing, China) for $1 \mathrm{~h}$. Diluted primary antibodies against TLR4 (1:500; Affinity Biosciences, OH, USA) and cluster of differentiation 14 (CD14) and CD11b (1:500; Bioss, Beijing, China) were incubated with the cells at $4{ }^{\circ} \mathrm{C}$ for $12 \mathrm{~h}$ and a fluorescein isothiocyanate (FITC)- labelled secondary antibody (1:1,000, Beyotime) was applied according to the manufacturer's instructions. The cell nuclei were stained with 4',6-diamidino-2-phenylindole (DAPI; Solarbio, Beijing, China) before placing the coverslip over the slides along with an anti-fluorescence quenching agent. Fluorescent staining was observed with a laser scanning confocal microscope (Nikon Instruments Inc., NY, USA).

\section{Western blotting}

The cells were washed three times with PBS before the total protein was harvested with the Minute Total Protein Extraction Kit (Invent Biotechnologies, Eden Prairie, USA). We added phosphatase inhibitor complex I (1:100, Aidlab, China) to lysis buffer (denaturing cell lysis buffer) prior to use. The protein concentration of each extract was quantified using the BCA Protein Assay Kit (Beyotime) according to the manufacturer's protocols. After the crude lysate had been resuspended in sodium dodecyl sulphate (SDS) buffer and incubated at $95^{\circ} \mathrm{C}$ for $10 \mathrm{~min}$, equal amounts of the protein samples (about 20-30 $\mu \mathrm{g}$ each) were loaded in separate lanes of a $12 \%$ gel for SDS-polyacrylamide gel electrophoresis. Following electrophoretic separation, the proteins were transferred to a polyvinylidene fluoride membrane (Millipore, Massachusetts, USA). The membranes were blocked with $5 \%$ milk powder for $2 \mathrm{~h}$ at room 


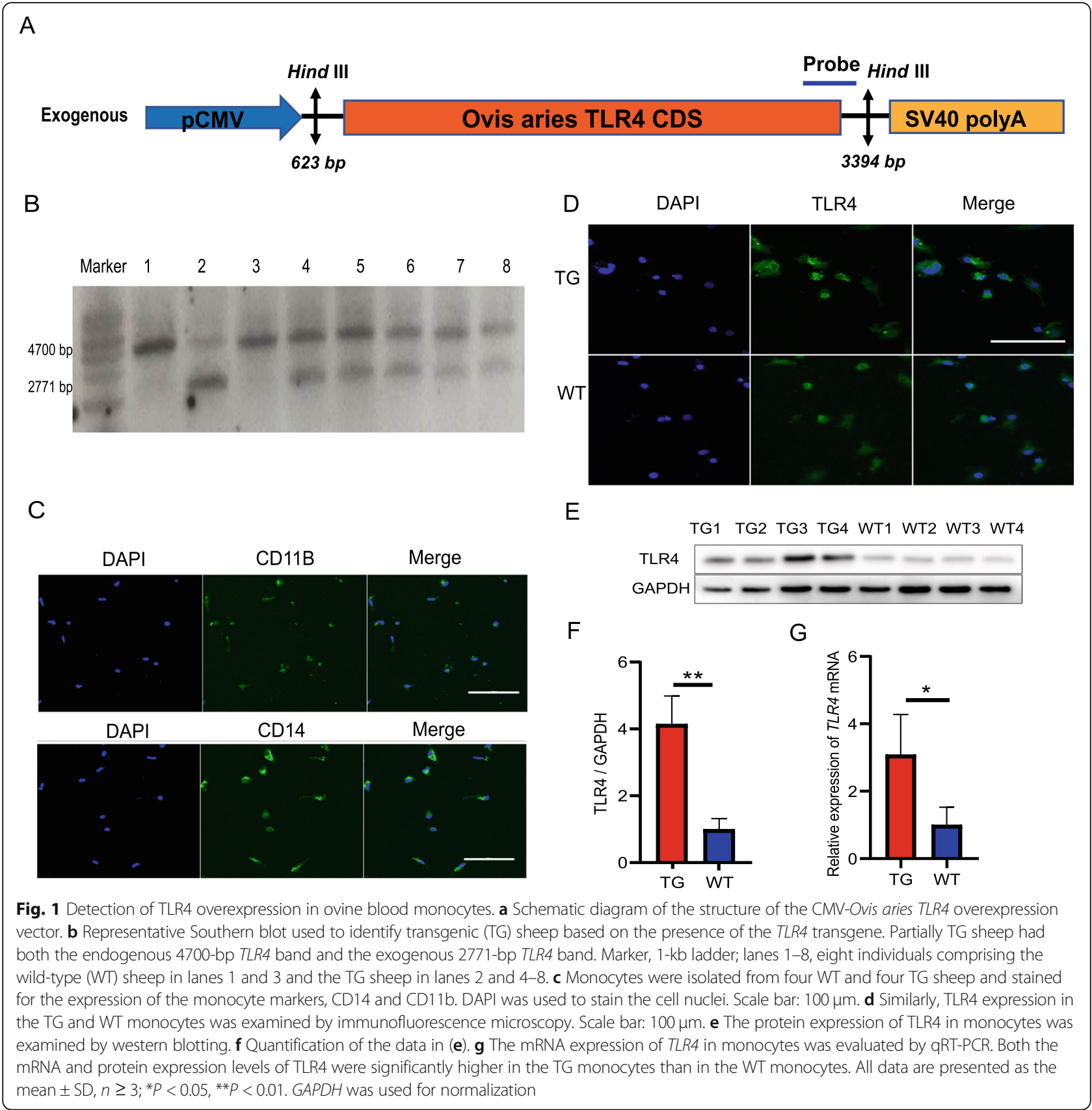

temperature. After incubation overnight with antibodies against TLR4 (AF7017, 1:500; Affinity Biosciences, OH, USA), Src (2109S, 1:1,000; Cell Signaling Technology, Inc., Boston, USA), p-Src (2101S, 1:1,000; Cell Signaling Technology), CAV1 (3238S, 1:1,000; Cell Signaling Technology), p-CAV1 (3251S, 1:1,000; Cell Signaling Technology), and GAPDH (D110016, 1:5,000; Sangon, Shanghai, China) at $4{ }^{\circ} \mathrm{C}$, the membranes were washed thoroughly with Tris-buffered saline containing $0.1 \%$ Tween 20 (TBST). The membranes were then incubated with a horseradish peroxidase-conjugated secondary antibody (A0208, 1:5,000; Beyotime). The membranes were visualized with an enhanced chemiluminescence system (Solarbio) according to the manufacturer's instructions.

Monocyte infection and colony-forming unit (CFU) counts The E. coli K12 strain DH5a and Staphylococcus aureus RN4220 were cultured in Luria-Bertani (LB) broth at $37^{\circ} \mathrm{C}$. The bacterial growth phase was measured by the absorbance of the bacterial suspension at $600 \mathrm{~nm}$. An optical density (OD) of $\sim 0.4$ ensured that bacteria were in the logarithmic growth phase. The number of bacteria was counted by plate counting through serial 10 -fold dilutions of the inoculum to LB agar. The bacteria were 
suspended and diluted to a concentration of $1 \times 10^{7}$ cells/mL in RPMI-1640 medium (Thermo Fisher Scientific, Waltham, USA) containing 10\% FBS. Before infection, monocytes were counted again and seeded in 6well culture plates (Corning, NY, USA). The monocytes were cultured for $12 \mathrm{~h}$ to ensure cell adherence to the well bottoms, washed three times in PBS without antibiotics, mixed with bacteria at a multiplicity of infection (MOI) of 10 , and then centrifuged at $200 \times g$ for $2 \mathrm{~min}$. The monocytes were subsequently incubated at $37^{\circ} \mathrm{C}$ in $5 \% \mathrm{CO}_{2}$ for the indicated times. The cells were washed three times with PBS containing gentamicin $(100 \mu \mathrm{g} / \mathrm{mL})$ and lysed with $0.1 \%$ Triton X-100 (Sigma-Aldrich, Saint Louis, USA) to release intracellular bacteria. The total intracellular CFU of bacteria was quantified by culture in agar after serial dilution.

For determination of the bacterial killing capacity of the monocytes, all samples were first incubated with E. coli for the same period $(15 \mathrm{~min})$. The extracellular bacteria were removed by washing the samples three times with PBS containing gentamicin $(100 \mu \mathrm{g} / \mathrm{mL})$. RPMI-1640 supplemented with 10\% FBS was added to the cells, and the cells were then incubated for the indicated times. The cells were washed twice with PBS and lysed with $0.1 \%$ Triton $\mathrm{X}-100$. The time to phagocytosis was counted from the time of bacterial addition. The data on the numbers of killed bacteria were obtained by subtracting the number of intracellular bacteria at $30 \mathrm{~min}$ from the same number at $15 \mathrm{~min}$.

\section{Quantitative reverse-transcription polymerase chain reaction ( $q R T-P C R$ )}

The qRT-PCR reactions were performed on an MX3000P instrument (Agilent Technologies, Santa Clara, USA) with the SYBR Premix Ex Taq II kit (TaKaRa, Kyoto, Japan). The total RNA of the sheep peripheral blood monocytes was extracted with an RNA extraction kit (Aidlab, Beijing, China), and a PrimeScript RT kit (TaKaRa) was used to reverse transcribe the RNA into cDNA. Primer pairs were designed by the primer design software Primer 3 and confirmed by the Primer- BLAST tool at the NCBI (National Center of Biotechnology Information) site. A melting curve analysis confirmed the presence of a single gene specific peak and the absence of primer dimers. Melting curve analysis consisted of $95^{\circ} \mathrm{C}$ for $15 \mathrm{~s}, 60^{\circ} \mathrm{C}$ for $1 \mathrm{~min}$, and $95^{\circ} \mathrm{C}$ for $30 \mathrm{~s}$.

The primer sequences used for qRT-PCR are presented in Supplementary Table S1.

For comparison of the expression of inflammatory factors between the transgenic and wild-type groups of sheep under $E$. coli challenge, the cells were treated with E. coli at a multiplicity of infection (MOI) of 10 and incubated for $30 \mathrm{~min}$, and total RNA was extracted after first washing the cells three times with PBS. The mRNA expression levels were normalized to those of a housekeeping gene, GAPDH. The cells treated with S. aureus underwent the same procedure as the $E$. coli cells. The data were analysed using the comparative $2^{-\Delta \Delta C T}$ method.

\section{Inhibitor treatment}

For analysis of the interactions among TLR4, caveolaedependent endocytosis, and Src signalling in E. coli internalization and elimination, monocytes were pretreated for $2 \mathrm{~h}$ with either $2 \mu \mathrm{mol} / \mathrm{L}$ Tak242 (MedChemExpress, Monmouth Junction, USA) -a TLR4 inhibitor, $3 \mu \mathrm{mol} / \mathrm{L}$ filipin-a caveolae-mediated endocytosis inhibitor (MedChemExpress), or $3 \mu \mathrm{mol} / \mathrm{L}$ dasatinib (MedChemExpress) - an Src inhibitor. After treatment, the cells were used for subsequent experiments.

\section{Monocyte endocytosis assay}

E. coli were labelled with pHrodo from a $\mathrm{pHrodo}^{\mathrm{in}}$ Red E. coli kit (Thermo Fisher Scientific). Before the powder was diluted in PBS ( $\mathrm{pH} 7.4$ ) to form a working solution, the mixture was sonicated for $30 \mathrm{~min}$ in the dark. Monocytes were plated in a 6-well plate (Corning) at $1 \times 10^{6}$ cells/well and incubated for $2 \mathrm{~h}$ at $37^{\circ} \mathrm{C}$. The monocytes were then infected with pHrodo- labelled $E$. coli at a ratio of 10:1 (bacteria:cells) in RPMI-1640 medium supplemented with $10 \%$ FBS. After centrifugation at $200 \times g$ for $2 \mathrm{~min}$, the cells in the 6 -well culture plates were further cultured for the indicated times. The assay was terminated at each time point by washing the cells three times with cold PBS, followed by the addition of $4 \%$ paraformaldehyde to each well. Subsequently, the cells were subjected to flow cytometry and microscopy studies.

\section{Flow cytometry}

The percentage of monocyte endocytosis was measured by the uptake of red fluorescent pHrodo Escherichia coli (Thermo Fisher Scientific). Briefly, $1 \times 10^{6}$ cells/well monocytes were treated with pHrodo- labelled E. coli at a ratio of 10:1 (bacteria:cells) in a 6-well plate. After indicated times incubation, cells were washed and fixed with $4 \%$ paraformaldehyde then harvested in PBS pH 7.4. Samples were analysed by a flow cytometer (Beckman Coulter). Live cells were gated by forward scatter and side scatter area, singlets were gated by forward scatter area and forward scatter height. $1 \times 10^{4}$ cells were collected, the PE channel was used to detect pHrodolabeled E. coli in cells. The pHrodo threshold was set based on the sample of cells without pHrodo addition and applied to all samples. The percentage of monocyte endocytosis was the proportion of positive pHrodo cells in total cells. Dates were analysed with FlowJo software. 


\section{Endosome pH}

Each sample had the same monocytes in the test wells and standard curve wells. Monocytes were infected with pHrodo- labelled E. coli for $10 \mathrm{~min}$ in 96-well culture plates and then washed with cold PBS. Noninternalized pHrodo- labelled E. coli was washed away. In addition, this time was treated as the starting point ( $0 \mathrm{~min})$. In standard curve wells, monocytes were treated for $30 \mathrm{~min}$ at a fixed $\mathrm{pH}(4.21,5.18,6.2,7.38$, or 8.16$)$ with PBS containing $1 \%$ Triton X-100. Monocytes in the test wells tested at a predetermined time. The time when noninternalized pHrodo- labelled E. coli was washed away was taken as time 0 . Fluorescence values were read at intervals using an emission wavelength of $590 \mathrm{~nm}$. The cell luminescence value without pHrodo- labelled E. coli was used as the background control. The sample values were compared with standard curves obtained using each sample.

\section{Colocalization assay}

E. coli was heat-inactivated at $90{ }^{\circ} \mathrm{C}$ for $30 \mathrm{~min}$. After being washed twice with $0.1 \mathrm{~mol} / \mathrm{L} \mathrm{NaHCO}_{3}(\mathrm{pH} 9.0)$, heatinactivated $E$. coli was incubated in $0.1 \mathrm{~mol} / \mathrm{L} \mathrm{NaHCO}_{3}$ containing $1 \mathrm{mg} / \mathrm{mL}$ FITC (Sigma-Aldrich, Saint Louis, USA) for $1 \mathrm{~h}$ at room temperature with gentle stirring. Monocytes were plated onto 8-well glass chamber slides at a concentration of $1 \times 10^{5}$ cells/well and incubated for $2 \mathrm{~h}$ at $37^{\circ} \mathrm{C}$ to allow the cells to adhere. The cells were infected with FITC- labelled E. coli at an MOI of 10 for 30 min. Before incubation at $37^{\circ} \mathrm{C}$, the plates were centrifuged to synchronize endocytosis. The cells were washed three times with PBS after incubation and then fixed with $4 \%$ paraformaldehyde for $20 \mathrm{~min}$, followed by the addition of $1 \%$ Triton X-100 to make the cells permeable. The cells were immunostained with EEA1 (ab2900, 1:500; Abcam, Cambridge, UK) or LAMP1 (ab67283, 1:500; Abcam). Alexa Fluor 647-conjugated antirabbit antibody (Beyotime) was used for detection.

\section{Cathepsin B activity assay}

Monocytes were collected by centrifugation and lysed in $100 \mu \mathrm{L}$ of prechilled cell lysis without inhibitors (Beyotime) on ice for $10 \mathrm{~min}$. Then, the cells were centrifuged at top speed for $5 \mathrm{~min}$, and the supernatant was transferred to a new tube. The protein concentration of each extract was quantified by a BCA Protein Assay Kit (Beyotime). The amount of total protein used for detection was the same. Each sample was measured using a cathepsin B activity assay kit (Yuanmu, Shanghai, China) according to the manufacturer's protocols. The OD was determined at $450 \mathrm{~nm}$. The sample value was obtained by the standard curve.

\section{Statistical analysis}

All data are shown as the mean \pm SD from no fewer than three independent experiments. The differences observed among samples were analysed with the independent-samples t-test and were considered statistically significant when $P<0.05$.

\section{Results \\ Detection of transgenic sheep overexpressing TLR4}

The TLR4 expression vector (Fig. 1a) was integrated into the genome of transgenic sheep bred during our previous study. Positive individuals were confirmed for use in the present study by Southern blotting. After digestion of the sheep genome with the restriction enzyme Hin$d \mathrm{III}$, the endogenous TLR4 fragment (4700 bp) was found in all sheep, while the exogenous TLR4 gene (2771 bp) was only identified in the transgenic sheep (Fig. 1b).

Monocytes are vital innate immune cells that play critical roles in the response to infection and inflammation through antigen presentation $[32,33]$. Therefore, we isolated monocytes from ovine peripheral blood to determine the level of TLR4 expression in these cells. The monocyte markers CD14 and CD11b were detected on the cell membranes by antibody staining (Fig. 1c), and TLR4 expression in the transgenic and wild-type sheep was compared at the transcription and protein levels (Fig. 1d-f). The results showed that the mRNA and protein levels of TLR4 were significantly higher $(P<0.05$ and $P<0.01$, respectively) in the transgenic ovine monocytes than in the wild-type monocytes.

\section{TLR4 overexpression leads to increased internalization and killing of $E$. coli and promotes the activation of multiple TLR4-mediated pathways}

The monocyte-mediated internalization of bacteria is an important antimicrobial reaction [34]. Here, the number of internalized E. coli in the TG and WT monocytes both increased with increasing infection time, although the levels of intracellular bacteria were significantly higher $(P<0.01$ for all time points) in the TG monocytes than in the WT monocytes when using an MOI of 10 (Fig. 2a). However, the numbers of internalized S. aureus in the TG and WT monocytes were not different at any infection time (Fig. S1A). Next, the monocytes were challenged for a fixed time with $E$. coli and then cultured for the indicated times (Fig. 2b). The bacterial burden in the TG monocytes was significantly higher $(P<0.01)$ than that in the WT monocytes when the endocytosis time was $15 \mathrm{~min}$. Both groups were treated with a TLR4 inhibitor, TAK242, which yielded similar results between the two groups $(P<0.01)$, in addition to a significant reduction in the number of bacteria carried by either group $(P<0.01)$. However, these differences between the TG and WT groups were not statistically significant after an endocytosis time of $30 \mathrm{~min}$. The changing number of E. coli bacteria internalized by the cells over 


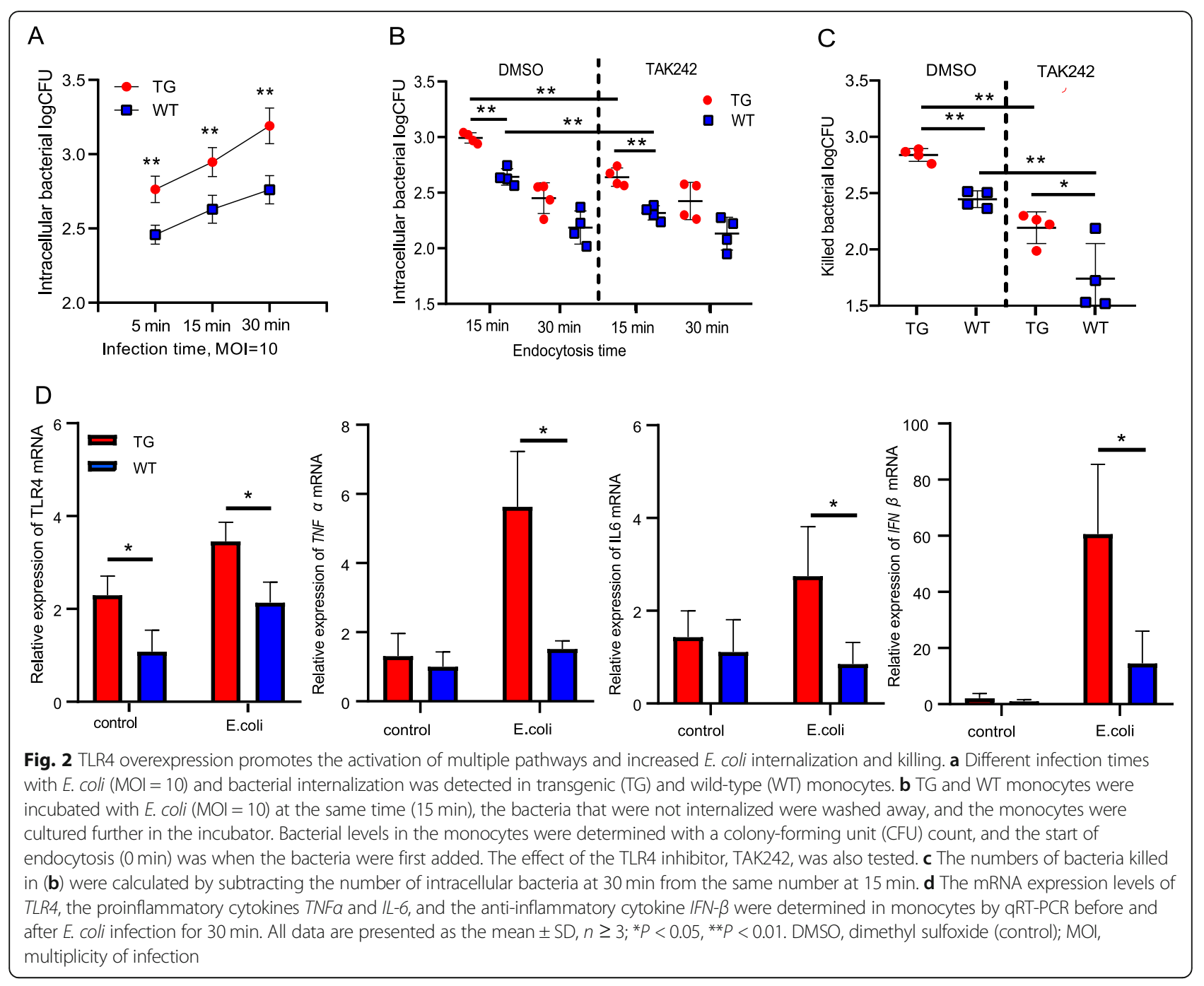

different endocytosis times can be attributed to the increased level of bacterial elimination by the monocytes with increasing endocytosis time (Fig. 2c). The elimination capacity of the TG group was significantly higher than that of the WT group regardless of whether the monocytes were treated with TAK242 $(P<0.01$ without inhibition, $P<0.05$ with inhibition). Furthermore, TAK242 significantly affected the bacterial killing capacity of both groups $(P<0.01)$.

The bacteria-induced activation of TLR4 often leads to the production of multiple cytokines to protect against infection [35, 36]. To elucidate how the overexpression of TLR4 influences pathway activation, we examined the production of TNF $\alpha$ (tumour necrosis factor $\alpha$ ) and $I L-6$ (interleukin 6) by the TIRAP-MyD88-dependent pathway and the production of IFN- $\beta$ (interferon $\beta$ ) by the TRAM-TRIF-dependent pathway by qRT-PCR during the early stages of infection. All cytokines were produced at significantly higher levels $(P<0.05)$ in the TG group than the WT group after $30 \mathrm{~min}$ of $E$. coli infection
(Fig. 2d). In the S. aureus infection experiment, TLR4 expression in the WT and TG groups did not change significantly after $30 \mathrm{~min}$ of incubation $(\mathrm{MOI}=10)$ (Fig. S1B).

\section{TLR4 overexpression promotes monocyte endocytosis}

To explore the effect of TLR4 overexpression on the ability of monocytes to endocytose bacteria, we used $E$. coli labelled with pHrodo. This unique fluorogenic dye is only incorporated into acidic cellular compartments and allows detection of these organelles by increasing the fluorescence intensity as the $\mathrm{pH}$ of the surroundings becomes more acidic. Endocytosis is a process accompanied by a rapid decrease in endosomal $\mathrm{pH}$ [15]. Internalized bacteria labelled with pHrodo are fluorescent and easily observed by microscopy, while extracellular bacteria are not fluorescent in the medium and are therefore not visible [37]. The results showed that the overexpression of TLR4 during the initial stages of bacterial infection (10 and $30 \mathrm{~min}$ ) led to more monocytes 
undergoing internalization, and the fluorescence signals from these cells were more intense (Fig. 3a). Flow cytometric analysis showed that the percentage of monocyte endocytosis of pHrodo- labelled E. coli in the TG group was significantly higher $(P<0.05)$ than that in the WT group for both $E$. coli infection times (Fig. 3b, c and Supplementary Fig. S2). After pretreatment with the TLR4 inhibitor, TAK242, this percentage was still significantly higher $(P<0.05)$ in the TG group than in the WT group, and the inhibitory effect of TAK242 on the TG monocytes was stronger than that on the WT monocytes (Fig. 3d and Supplementary Fig. S3). These results suggest that the overexpression of TLR4 enhances monocyte endocytosis of E. coli.

\section{TLR4 overexpression promotes caveolae formation}

Caveolae-mediated endocytosis is reported to be an extremely important pathway for realizing pathogen internalization [38], particularly towards E. col [39]. CAV1 is a signalling protein associated with caveolae; its phosphorylation by the tyrosine kinase $\mathrm{Src}$ activates CAV1 and promotes caveolae formation [20, 26]. To investigate the role of caveolae-mediated endocytosis in the underlying mechanism of TLR4 overexpression promoting $E$. coli endocytosis, the key proteins involved in caveolae formation, Src and CAV1, as well as their phosphorylation levels, were detected during the early stages of $E$. coli infection. The results showed that the phosphorylation of Src and CAV1 in the TG group started earlier than that in the WT group (Fig. 4a). Furthermore, at each time point, the levels of Src and CAV1 phosphorylation were significantly higher than those of the WT group. There were particularly significant differences in Src phosphorylation at $30 \mathrm{~min}$ and CAV1 phosphorylation at $60 \mathrm{~min}(P<0.01$ for both; Fig. $4 \mathrm{~b}, \mathrm{c})$. However, the protein levels of Src and CAV1 were not significantly different between the two groups except for CAV1 at $10 \mathrm{~min}$ (Fig. 4d, e). These results suggest that the overexpression of TLR4 enhances Src and CAV1 phosphorylation, which can lead to increased levels of caveolae-mediated endocytosis during the initial stage of E. coli infection.

\section{Inhibition of caveolae-mediated endocytosis reduces the ability of TLR4-overexpressing monocytes to internalize and kill E. coli}

To better clarify the role of caveolae-mediated endocytosis in the antimicrobial activity of monocytes overexpressing TLR4, we performed experiments with various inhibitors. Prior to western blotting, TLR4-overexpressing monocytes were pretreated with either dasatinib (an Src inhibitor), filipin (a strong caveolae-mediated endocytosis inhibitor), or TAK242 (a TLR4 inhibitor) and subjected to $30 \mathrm{~min}$ of E. coli infection. The levels of phosphorylated Src and
CAV1 in all treatment groups decreased (Fig. 5a-c), especially those of $\mathrm{p}$-Src in the dasatinib and TAK242 treatment groups $(P<0.01)$ and $\mathrm{p}-\mathrm{CAV} 1$ in the filipin treatment group $(P<0.01)$. However, there were no significant differences in the Src and CAV1 protein levels following inhibitor treatment (Fig. 5a, d, e). Flow cytometric analysis of the percentage of monocyte endocytosis of pHrodo- labelled E. coli in the untreated TLR4overexpressing monocytes was compared with that of the dasatinib- and filipin-treated cells. Both inhibitors significantly reduced $(P<0.01)$ the percentage of endocytosis (Fig. 5f, g and Supplementary Fig. S4). The same results were observed for the intracellular E. coli CFU count (Fig. 5h) and the numbers of killed E. coli based on the CFU count (Fig. 5i). These results showed that the antimicrobial activity of the TLR4-overexpressing monocytes can be reduced by inhibitors of caveolae-mediated endocytosis. This finding suggests that caveolae-mediated endocytosis plays an important role in the antibacterial activity of monocytes overexpressing TLR4.

\section{TLR4 overexpression promotes endosome acidification and maturation}

To elucidate the enhanced E. coli killing capacity of TG monocytes, we examined this issue from the perspective of endosome maturation. The function of the endosome network is to collect internalized cargoes and ferry them to their final destinations [40]. In this process, endosomes undergo a multitude of changes, including a drop in luminal $\mathrm{pH}$. Here, pHrodo- labelled $E$. coli was used to compare endosomal pH changes between the TG and WT groups. Within $1 \mathrm{~h}$ after infection, the endosomal $\mathrm{pH}$ of the TG group exhibited a steeper decline than that of the WT group (Fig. 6a). Furthermore, the pH of the TG group was significantly lower than that of the WT group at all time points after 0 min $(P<0.05$ to $P<$ 0.01 ). When the TG cells were pretreated with the inhibitors dasatinib, filipin, and TAK242, all inhibitors were found to significantly reduce the acidification of the endosomes $(P<0.01$ for all inhibitors and time points after $0 \mathrm{~min}$; Fig. $6 \mathrm{~b}$ ). To further verify the influence of TLR4 overexpression on the maturation of the endosome, we used FITC- labelled E. coli to analyse colocalization with early endosome antigen 1 (EEA1, a primary endosomal marker) or lysosomal associated membrane protein 1 (LAMP1, a lysosomal marker). From the fluorescence images, it was observed that for both the EEA1 and LAMP1 markers, the TG group showed greater colocalization than the WT group (Fig. 6c, d). These results demonstrated that the overexpression of TLR4 can promote endosome acidification and that this acidification is regulated by the Src, caveolae-mediated endocytosis, and TLR4 pathways. In addition, the colocalization experiment with bacteria and endosomal 

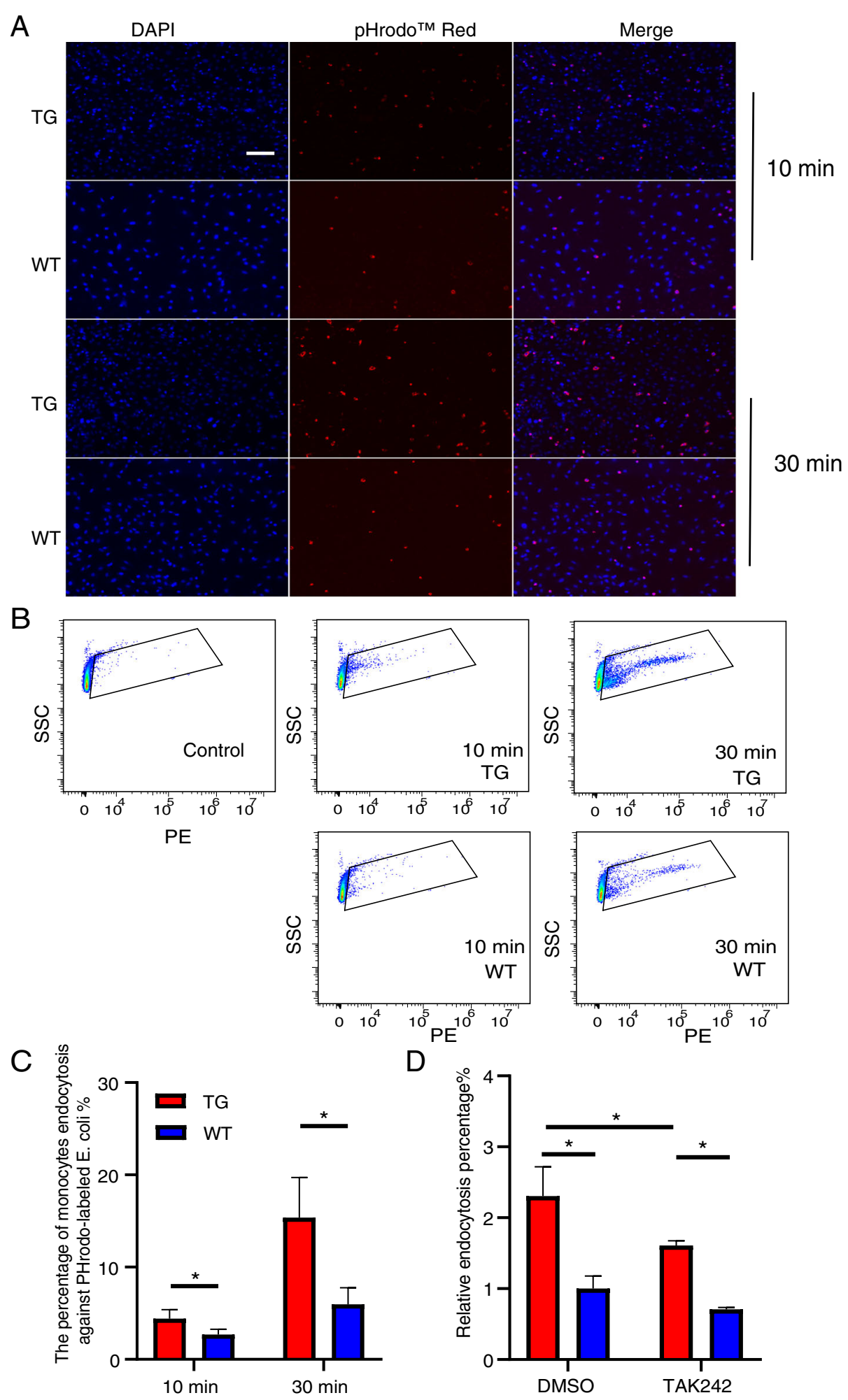

Fig. 3 TLR4 overexpression promotes monocyte endocytosis. a The endocytosis of pHrodo-labelled E. coli by monocytes in the transgenic (TG) and wild-type (WT) groups was observed by fluorescence microscopy. Scale bar: $100 \mu \mathrm{m}$. b Flow cytometric analysis of the percentage of monocyte endocytosis of the pHrodo- labelled E. coli after $10 \mathrm{~min}$ and $30 \mathrm{~min}$ of infection. c The effect of pretreatment with the TLR4 inhibitor TAK242 on monocyte endocytosis of pHrodolabelled E. coli. All data are presented as the mean $\pm \mathrm{SD}, n \geq 3 ;{ }^{*} P<0.05$, ${ }^{*} P<0.01$. DMSO, dimethyl sulfoxide (control) 


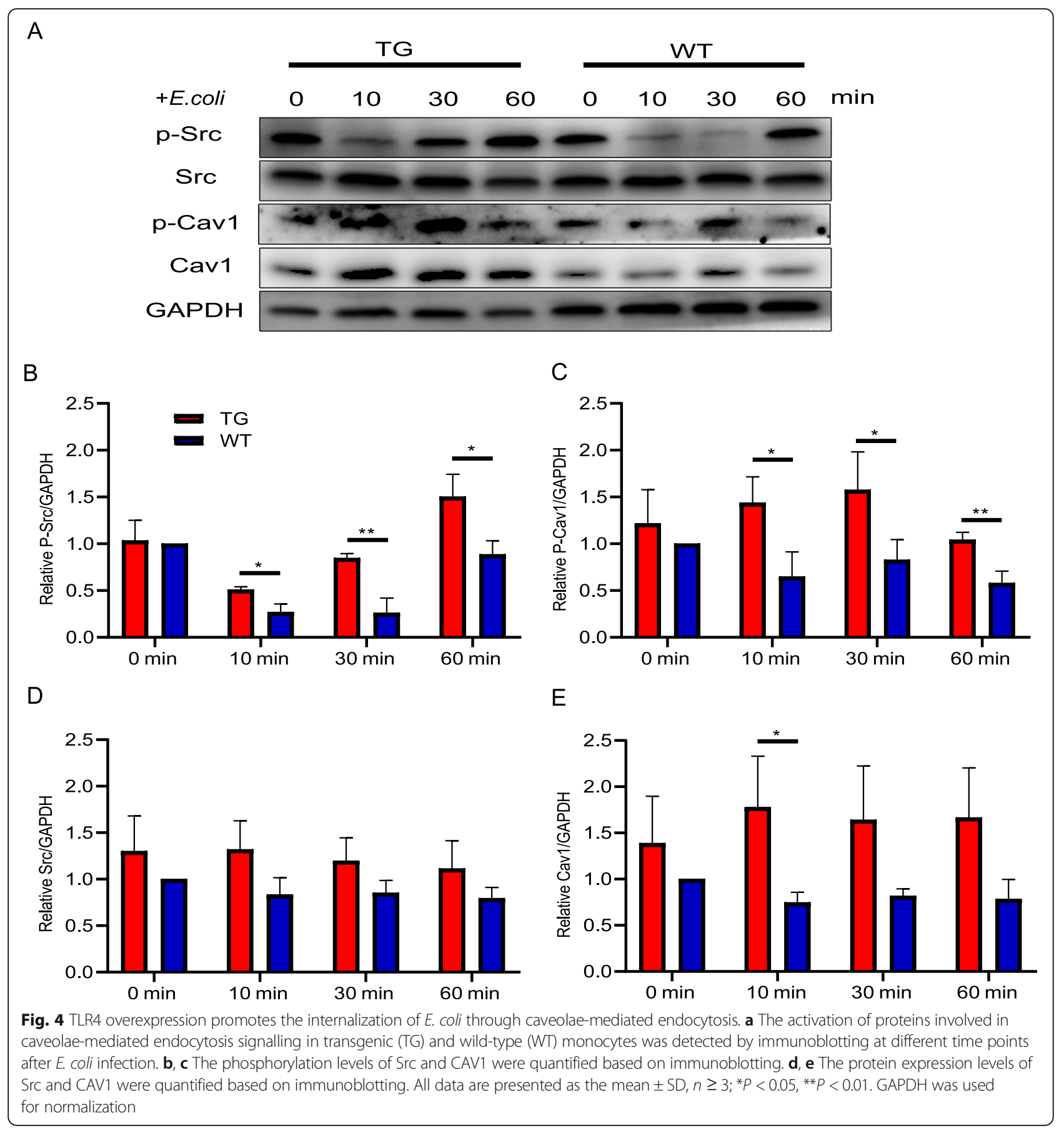

markers for different stages of maturation provides another perspective on how the overexpression of TLR4 promotes endosomal maturation.

\section{TLR4 overexpression promotes cathepsin B activity}

Cathepsin $\mathrm{B}$ is a kind of $\mathrm{pH}$-activated protease that is important in protein degradation [41]. This molecule is present in endosomes, and changes in endosomal $\mathrm{pH}$ modulate cathepsin B activity [42]. Cathepsin B activity was examined to further clarify the effect of TLR4 overexpression on the protein degradation of monocytes. In our results, the cathepsin B activity in the TG monocytes was significantly higher $(P<0.01$ for all time points except $0 \mathrm{~min}$ ) than that in the WT monocytes when $E$. coli was infected using an MOI of 10 . The levels in the TG group increased steeply with increasing infection time in an hour (Fig. 7a). After 30 min of infection with E. coli, the TG cells pretreated with the inhibitors dasatinib, filipin, and TAK242 had significantly reduced cathepsin B activity $(P<0.01)($ Fig. $7 b)$. 


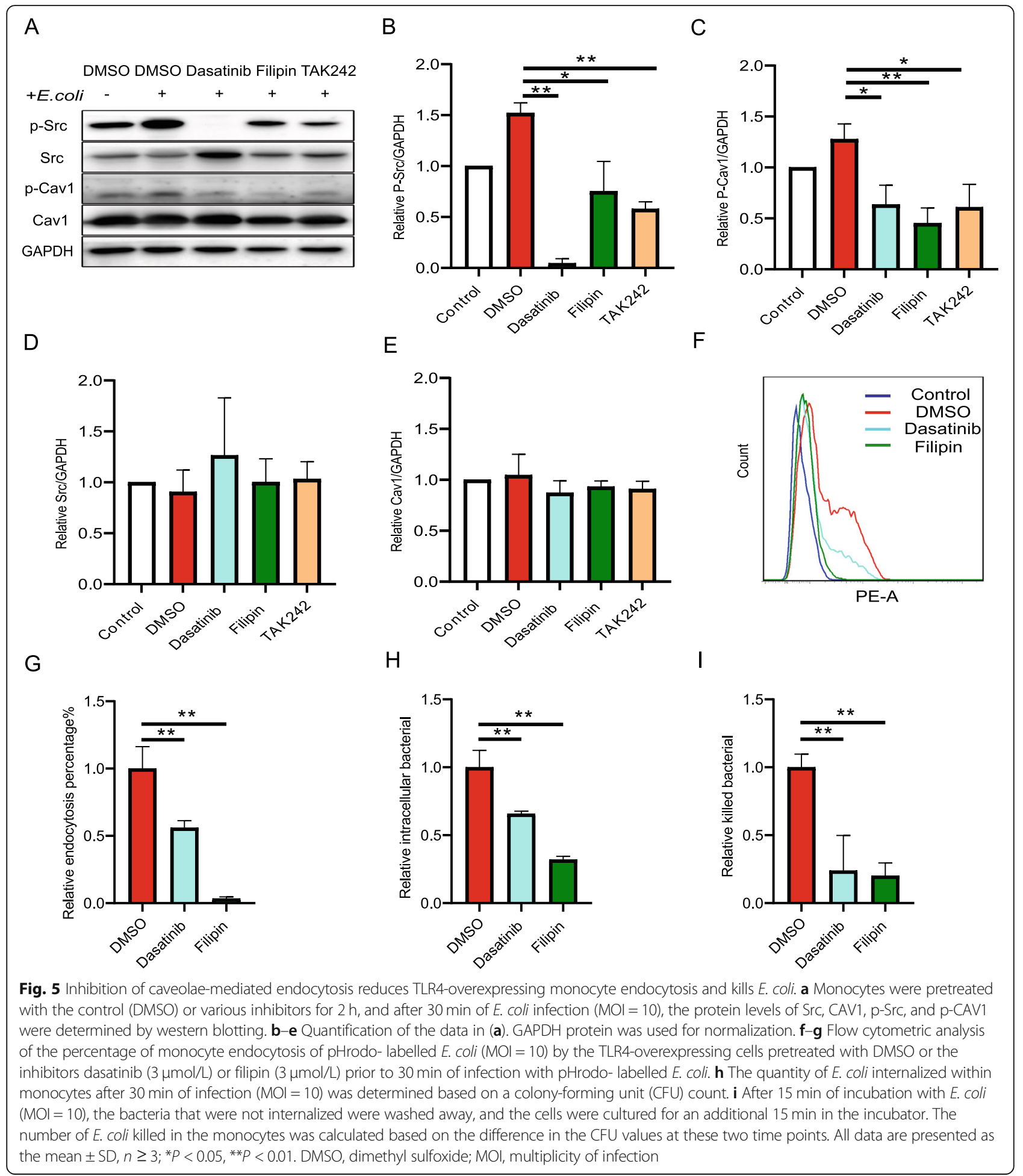

\section{Discussion}

TLR4 is a pattern-recognition receptor that plays a key role in the resistance of host immune cells to Gramnegative bacteria. When TLR4 binds to its specific ligands, it triggers the activation of the innate immune response [43]. Several studies have focused on the function of TLR4 in bacterial infection. TLR4-deficient mice are more susceptible to infection than control mice and have higher bacterial loads [17, 44]. TLR4-mutant enterocytes exhibit decreased sensitivity to LPS compared with wild-type cells [45]. Mice overexpressing TLR4 show greater protection against Salmonella infection because of their improved 

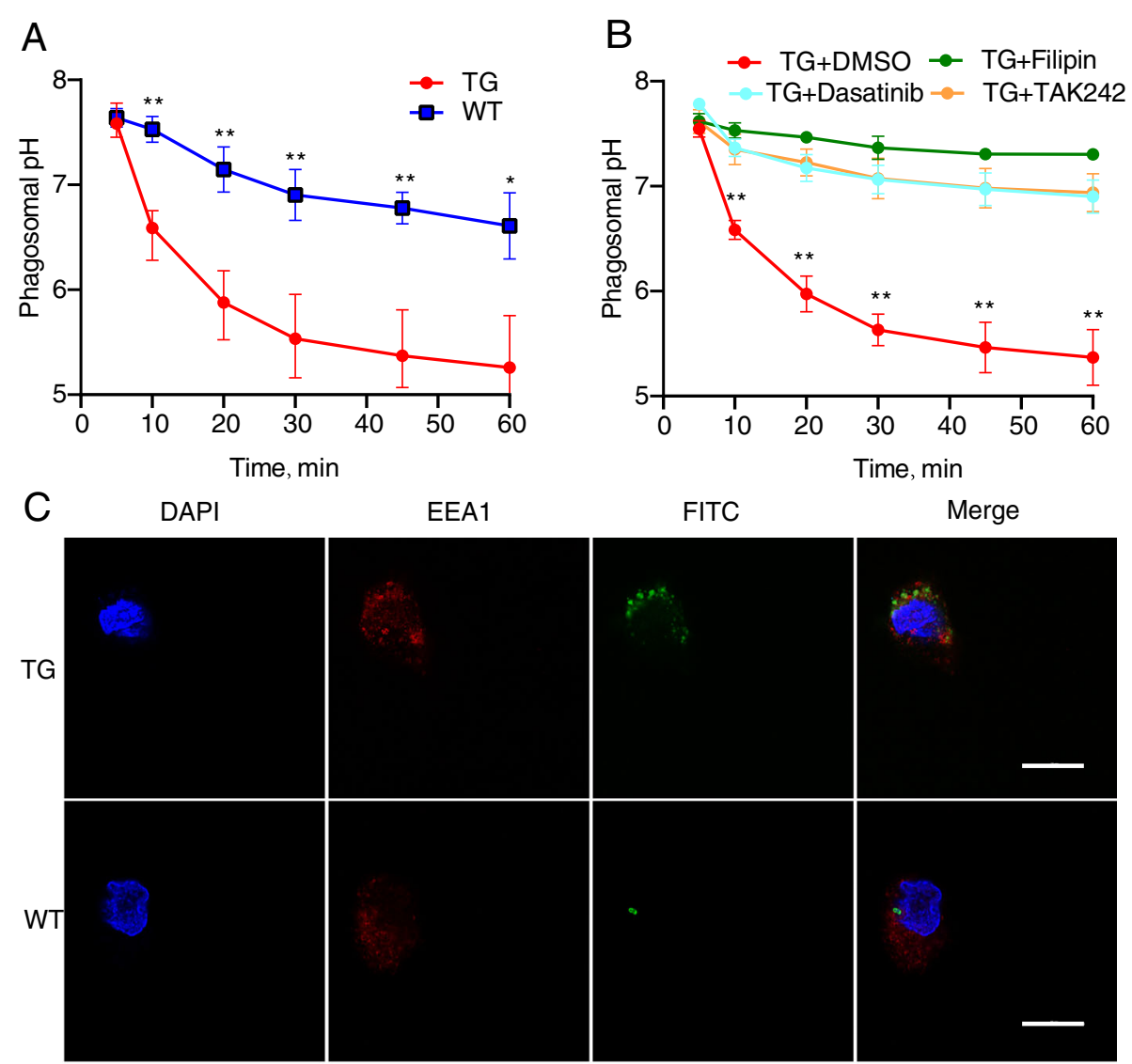

EEA1

FITC

Merge

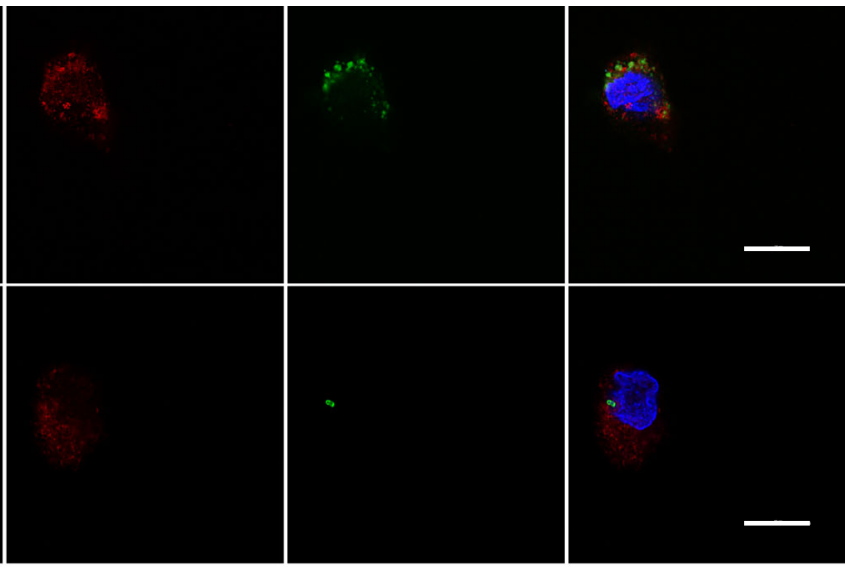

D DAPI

LAMP1

FITC

Merge

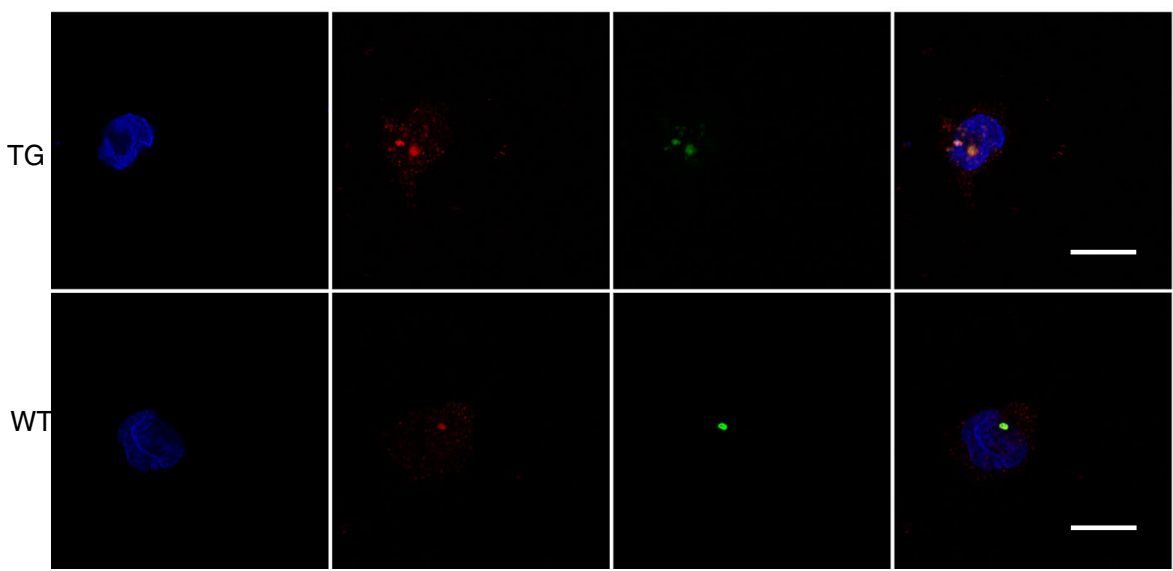

Fig. 6 TLR4 overexpression promotes endosome maturation. a The endosomal pH values of transgenic (TG) and wild-type (WT) monocytes were assessed following infection with pHrodo- labelled $E$. coli $(\mathrm{MOI}=10)$. Fluorescence values were read at intervals using an emission wavelength of $590 \mathrm{~nm}$. Each sample had its own standard curves. The values were compared with standard curves obtained using corresponding sheep monocytes treated for $30 \mathrm{~min}$ at a fixed pH $(4.21,5.18,6.2,7.38$, or 8.16$)$ in phosphate-buffered saline containing $1 \%$ Triton $\mathrm{X}-100$. The start of the experiment ( 0 min) was when the bacteria were first added. $\mathbf{b}$ Effects of inhibitor treatment ( $2 \mu \mathrm{mol} / \mathrm{L}$ TAK2 $42,3 \mu \mathrm{mol} / \mathrm{L}$ dasatinib, and $3 \mu \mathrm{mol} / \mathrm{L}$ filipin) on the endosomal $\mathrm{pH}$ of the TG and WT monocytes. Dimethyl sulfoxide (DMSO) was used as the control. c Fluorescence images of FITC- labelled E. coli colocalization with the primary endosomal marker EEA1 in the TG and WT monocytes after 30 min of infection. Scale bar: $10 \mu \mathrm{m}$. d Fluorescence images of FITC- labelled E. coli colocalization with the lysosomal marker LAMP1 in the TG and WT monocytes after 30 min of infection. Scale bar:10 $\mu$ m. All data are presented as the mean $\pm S D, n \geq 3 ;{ }^{*} P<0.05$, ${ }^{* *} P<0.01$. DAPI, cell nuclei stain 
A

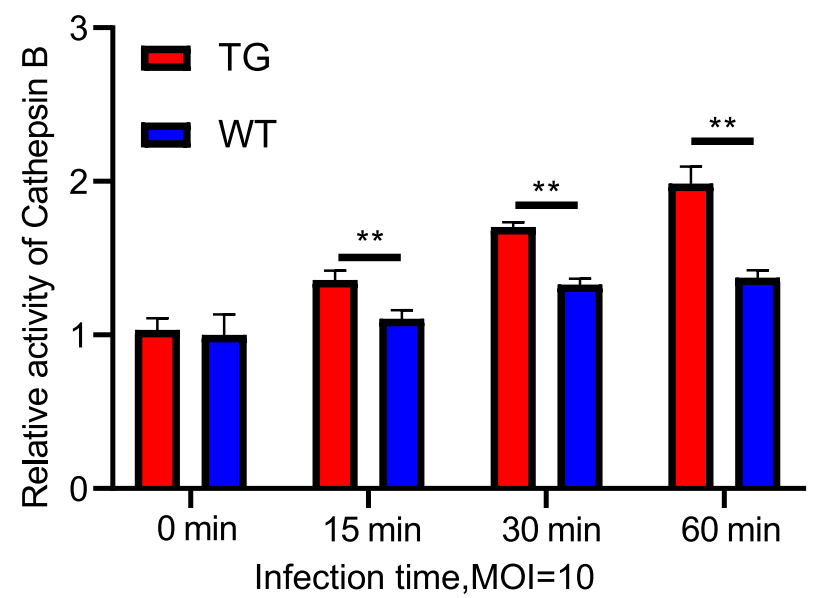

B

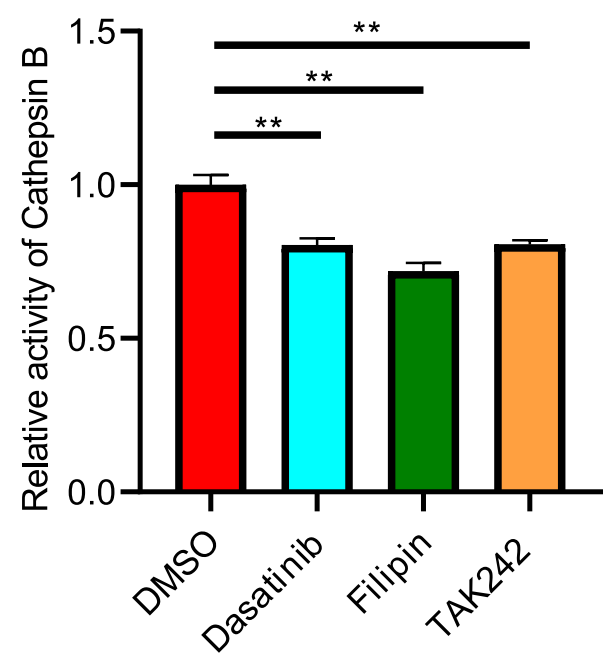

Fig. 7 TLR4 overexpression enhances cathepsin B activity. a The relative cathepsin B activity of transgenic (TG) and wild-type (WT) monocytes was assessed following infection with $E$. coli for different times $(\mathrm{MOI}=10)$. b Monocytes were pretreated with the control (DMSO) or various inhibitors for $2 \mathrm{~h}$, and after 30 min of E. coli infection $(\mathrm{MOI}=10)$, cathepsin B activity was compared. All data are presented as the mean $\pm S D$, $n \geq 3 ;{ }^{*} P<0.05$, ${ }^{* *} P<0.01$. DMSO, dimethyl sulfoxide; MOI, multiplicity of infection

control of bacterial growth in target organs and the increased expression of important immune response genes in their spleen [46]. These results demonstrated that TLR4 has extraordinary functional importance in endocytosis and inflammatory regulation as part of the host defence. Mechanistic studies have shown that the overexpression of TLR4 can efficiently and rapidly activate the TIRAP-MyD88-dependent pathway, while also promoting the innate antiviral effect by activating the TRAM-TRIF-dependent pathway [30]. In addition, during the internalization of $E$. coli, the expression levels of TLR4, MAPKs, and scavenger receptors were all higher in the TLR4-overexpressing transgenic sheep than in the wild-type sheep. The level of actin polymerization and the adhesive capacity of sheep monocytes are also higher in the transgenic sheep than the control sheep [31]. However, the defence mechanisms involved in the protective effect of TLR4 overexpression in sheep against invading pathogens are still not fully understood. In this study, using monocytes isolated from the peripheral blood of transgenic sheep, the expression of TLR4 at the mRNA and protein levels was observed to be significantly higher than that in the WT monocytes. After E. coli infection, the mRNA level of TLR4 increased in both groups but remained significantly higher in the TG group. The production of TNF $\alpha$ and $I L-6$ along the TIRAP-MyD88dependent pathway and the production of IFN- $\beta$ by the TRAM-TRIF-dependent pathway were compared between the two groups, and the TG group showed significantly higher expression of these factors than the WT group.
Since TLR4 is the only TLR that uses all four adaptors and activates both of these pathways [43], these two pathways are not activated simultaneously. Instead, the activation of these pathways is regulated by the location of TLR4. Higher activation of the TRAM-TRIF-dependent pathway indicates that more TLR4 is transferred from the cell surface to endosomes. Thus, the endocytosis pathway can activate the TRAM-TRIF-dependent pathway, which is illustrated by the TG group exhibiting higher levels of endocytosis than the WT group. This finding is consistent with other studies $[11,47,48]$. This inference was validated by experiments using monocytes infected with $E$. coli followed by CFU counts. However, there was no difference in Gram-positive bacteria. Inhibition of the TLR4 pathway significantly reduced the endocytosis and killing capacity of monocytes specific to the Gram-negative bacteria.

Endocytosis during the early stages of infection was further examined in the TG and WT monocytes using pHrodo- labelled E. coli. We found that while the percentage of monocyte endocytosis of pHrodo- labelled $E$. coli in the two groups increased with increasing infection time, the TG monocytes exhibited a higher percentage of endocytosis. Furthermore, the TLR4 inhibitor TAK242 reduced the percentage of internalization to a greater degree in the TG group. This finding may be attributable to TG monocytes having more TLR4 receptors on their surface, leading to more sensitive bacterial detection and more monocytes participating in bacterial internalization. 
Cells have evolved a variety of strategies to endocytose particles, solutes, and bacteria [49]. TLR4 signalling is associated with receptor internalization and trafficking, and which endocytosis pathways are used during these processes is still not fully understood. The caveolae share a lipid composition with plasma membrane rafts and represent a subdomain that is stabilized by caveolin proteins. The formation of caveolae is highly complex and regulated by cellular processes [50]. It has been noted that rafts act as potential sites for LPS to interact with CD14, and TLR4, TLR4 and accessory proteins can associate with plasma membrane rafts. The TLR4-raft association is stimulated under LPS [48]. However, caveolae involvement in TLR4-mediated endocytosis has not been fully elucidated. Recent studies have shown that the deficiency of the protein LAPF (lysosome-associated and apoptosis-inducing protein containing $\mathrm{pH}$ and FYVE domains), which affects the TLR4 pathway, can impair the phagocytosis and killing of E. coli by influencing caveolae complex formation in macrophages of mice [21]. Here, by detecting the phosphorylation of key proteins, we aimed to determine whether the higher endocytosis and killing capacity of the TG monocytes was caused by increased levels of caveolae-mediated endocytosis. We found that the TG group exhibited earlier phosphorylation of Src and CAV1 following infection, and the levels of phosphorylated Src and CAV1 in the TG group were higher than those in the WT group at the same time points post-infection. In addition, Src is required for Src-CAV1 complex formation and bacterial endocytosis. The inhibition of Src and caveolae-mediated endocytosis reduced the endocytosis and bactericidal capacity of the TG group, which further indicated that caveolaemediated endocytosis was implicated in the enhanced capacity of TG monocytes for antimicrobial defence.

Acidification and maturation of endosomes promote the killing of intracellular bacteria $[51,52]$. However, whether TLR4 causes endosome acidification is controversial $[16,53]$. We next explored the acidification and maturation of endosomes to examine the enhanced killing of intracellular bacteria by the TG group. The TG group showed increased acidification of the endosome, and the internalized bacteria showed greater colocalization with both the primary endosomal marker EEA1 and the lysosomal marker LAMP1 than those of the WT group. Inhibitors of Src, caveolae-mediated endocytosis, and TLR4 all reduced the degree of acidification in the TG group. Cathepsin B activity as an indicator of protein degradation ability was also examined. The activity of cathepsin $\mathrm{B}$ is strongly affected by $\mathrm{pH}$, and increased $\mathrm{pH}$ leads to a reduction in cathepsin B activity [54]. Our results of cathepsin B activity showed the same trend as phagosome acidification. All the results may indicate that TLR4 and caveolae-mediated endocytosis regulate endosome acidification and maturation.

\section{Conclusions}

Our results provide novel evidence of the underlying antibacterial mechanisms of TLR4 in the innate immunity of sheep. TLR4 overexpression in monocytes enhances their internalization and killing of bacteria via caveolae-dependent endocytosis and promotes their ability to fight against pathogens during the earlier stages of infection; these are the first results from a large animal model. In addition, for the first time, the $\mathrm{pH}$ of endosomes was detected by artificially controlling the expression of TLR4, and it was proven that in the case of exogenous stimuli, the increase in TLR4 expression was correlated with the decrease in endosomal $\mathrm{pH}$. A significant decrease in $\mathrm{pH}$ can inhibit the growth of bacteria and reflects the maturation of endosomes. Further experimental results indicate that TLR4 and caveolaemediated endocytosis regulate endosome acidification and maturation, and the overexpression of TLR4 can promote the maturation of endosomes and the killing of E. coli by enhancing the phosphorylation of Src and CAV1. Src and CAV1 can be used as potential targets to provide a theoretical basis for future breeding for disease resistance.

\begin{abstract}
Abbreviations
TLR4: Toll-like receptor 4; E. coli: Escherichia coli; CAV1: Caveolin 1; TIR: Tollinterleukin 1 receptor; TIRAP: Toll-interleukin 1 receptor domain containing adaptor protein; MyD88: Myeloid differentiation factor 88; TRAM: TRIF-related adaptor molecule; TRIF: TIR domain containing adaptor-inducing interferonB; MD2: Myeloid differentiation protein 2; LPS: Lipopolysaccharide; MAPK: Mitogen-activated protein kinase; MAL: MyD88 adapter-like; PBS: Phosphate-buffered saline; FBS: Fetal bovine serum; FITC: Fluorescein isothiocyanate; CD14: Differentiation 14; DAPI: 4',6-Diamidino-2-phenylindole; SDS: Sodium dodecyl sulfate; TBST: Tris-buffered saline containing 0.1\% Tween 20; S. aureus: Staphylococcus aureus; LB: Luria-Bertani; OD: Optical density; qRT-PCR: Quantitative reverse-transcription polymerase chain reaction; CFU: Colony-forming unit; TG: Transgenic; WT: Wild-type;

DMSO: Dimethyl sulfoxide; TNFa: Tumour necrosis factor a; IL-6: Interleukin 6; IFN- $\beta$ : Interferon $\beta$; MOI: Multiplicity of infection; EEA1: Early endosome antigen 1; LAMP1: Lysosomal associated membrane protein 1;

LAPF: Lysosome-associated and apoptosis-inducing protein containing PH and FYVE domains
\end{abstract}

\section{Supplementary Information}

The online version contains supplementary material available at https://doi. org/10.1186/s40104-021-00585-z.

Additional file 1: Table S1. Gene-specific primers for quantitative realtime polymerase chain reaction (qRT-PCR).

Additional file 2: Figure S1. (A) Bacterial internalization was detected in transgenic (TG) and wild-type (WT) monocytes after different periods of incubation with Staphylococcus aureus $(\mathrm{MOI}=10)$. (B) TLR4 expression of transgenic (TG) and wild-type (WT) monocytes before and after $30 \mathrm{~min}$ of $S$. aureus infection $(\mathrm{MOI}=10)$.

Additional file 3: Figure S2. Flow cytometric analysis of the percentage of monocyte endocytosis of pHrodo- labelled E. coli after 10 min and 30 min of infection in the TG group and the WT group.

Additional file 4: Figure S3. Flow cytometric analysis of the effect on endocytosis of pHrodo- labelled E. coli in both groups of monocytes pretreated with TAK242. 
Additional file 5: Figure S4. Flow cytometric analysis of the percentage of monocytes that endocytosed pHrodo- labelled E. coli $(\mathrm{MOI}=10)$ in the TLR4-overexpressing cells pretreated with DMSO or the inhibitors dasatinib $(3 \mu \mathrm{mol} / \mathrm{L})$ or filipin $(3 \mu \mathrm{mol} / \mathrm{L})$ prior to $30 \mathrm{~min}$ of infection with E. coli.

\section{Acknowledgements}

Not applicable.

\section{Authors' contributions}

$Y L, Y L$ and $Z L$ designed the project and $Y L$ performed the experiments. Data curation and Formal analysis was by $Y L, Y L$ and SD. Funding acquisition was by ZL. Written by $Y L$. Discussion was carried out by $Y L, Y L, Y Z, X X$, and RZ. Blood samples were collection by $Y Z, J Z$ and $X Z$. All authors contributed to the article and approved the submitted version.

\section{Funding}

This work was supported by National Science and Technology Major Project of China (2016ZX08008-003).

\section{Availability of data and materials}

The data analyzed during the current study are available from the corresponding author on reasonable request.

\section{Declarations}

\section{Ethics approval and consent to participate}

The sample collection procedures were performed in accordance with a protocol from the Animal Welfare Committee of the China Agricultural University (Permit Number: XK662)

\section{Consent for publication}

All the authors read and agree to the content of this paper and its publication.

\section{Competing interests}

All authors declare that they have no conflict of interest.

\section{Author details}

${ }^{1}$ Beijing Key Laboratory for Animal Genetic Improvement, National Engineering Laboratory for Animal Breeding, Key Laboratory of Animal Genetics and Breeding of the Ministry of Agriculture, College of Animal Science and Technology, China Agricultural University, Beijing, China. ${ }^{2}$ Tianjin Institute of Animal Sciences, Tianjin, China. ${ }^{3}$ State Key Laboratory of Agrobiotechnology, College of Biological Sciences, China Agricultural University, Beijing, China. ${ }^{4}$ Institute of Laboratory Animal Sciences, Chinese Academy of Medical Sciences and Comparative Medicine Center, Peking Union Medical College, Beijing, China.

Received: 20 December 2020 Accepted: 16 March 2021

Published online: 10 May 2021

\section{References}

1. Akira S, Takeda K. Toll-like receptor signaling. Nat Rev Immunol. 2004;4(7): 499-511. https://doi.org/10.1038/nri1391.

2. Kawai T, Akira S. Toll-like receptors and their crosstalk with other innate receptors in infection and immunity. Immunity. 2011;34(5):637-50. https:// doi.org/10.1016/j.immuni.2011.05.006.

3. Visintin A, Mazzoni A, Spitzer JH, Wyllie DH, Dower SK, Segal DM. Regulation of Toll-like receptors in human monocytes and dendritic cells. J Immunol. 2001;166(1):249-55. https://doi.org/10.4049/jimmunol.166.1.249.

4. Akira S, Uematsu S, Takeuchi O. Pathogen recognition and innate immunity. Cell. 2006;124(4):783-801. https://doi.org/10.1016/j.cell.2006.02.015.

5. Ginhoux F, Jung S. Monocytes and macrophages: developmental pathways and tissue homeostasis. Nat Rev Immunol. 2014;14(6):392-404. https://doi. org/10.1038/nri3671.

6. Barton GM, Kagan JC. A cell biological view of Toll-like receptor function: regulation through compartmentalization. Nat Rev Immunol. 2009;9(8):53542. https://doi.org/10.1038/nri2587.
7. Kagan JC, Su T, Horng T, Chow A, Akira S, Medzhitov R. TRAM couples endocytosis of Toll-like receptor 4 to the induction of interferon- $\beta$. Nat Immunol. 2008;9(4):361-8. https://doi.org/10.1038/ni1569.

8. Kagan JC, Medzhitov R. Phosphoinositide-mediated adaptor recruitment controls Toll-like receptor signaling. Cell. 2006;125(5):943-55. https://doi. org/10.1016/j.cell.2006.03.047.

9. Gangloff M. Different dimerisation mode for TLR4 upon endosomal acidification? Trends Biochem Sci. 2012;37(3):92-8. https://doi.org/10.1016/j. tibs.2011.11.003.

10. Perkins DJ, Richard K, Hansen A, Lai W, Nallar S, Koller B, et al. Autocrineparacrine prostaglandin E2 signaling restricts TLR4 internalization and TRIF signaling. Nat Immunol. 2018;19(12):1309-18. https://doi.org/10.1038/s41 590-018-0243-7.

11. Zanoni I, Ostuni R, Marek LR, Barresi S, Barbalat R, Barton GM, et al. CD14 controls the LPS-induced endocytosis of Toll-like receptor 4. Cell. 2011; 147(4):868-80. https://doi.org/10.1016/j.cell.2011.09.051.

12. Murase M, Kawasaki T, Hakozaki R, Sueyoshi T, Putri DDP, Kitai Y, et al. Intravesicular acidification regulates lipopolysaccharide inflammation and tolerance through TLR4 trafficking. J Immunol. 2018;200(8):2798-808. https://doi.org/10.4049/jimmunol.1701390.

13. Husebye $H$, Halaas $O$, Stenmark H, Tunheim $G$, Sandanger $O$, Bogen B, et al. Endocytic pathways regulate Toll-like receptor 4 signaling and link innate and adaptive immunity. EMBO J. 2006;25(4):683-92. https://doi.org/10.1038/ sj.emboj.7600991.

14. McNally KE, Cullen PJ. Endosomal retrieval of cargo: Retromer is not alone. Trends Cell Biol. 2018;28(10):807-22. https://doi.org/10.1016/j.tcb.2018.06.005.

15. Kinchen JM, Ravichandran KS. Phagosome maturation: going through the acid test. Nat Rev Mol Cell Biol. 2008;9(10):781-95. https://doi.org/10.1038/ nrm2515.

16. Blander JM, Medzhitov R. Regulation of phagosome maturation by signals from Toll-like receptors. Science. 2004;304(5673):1014-8. https://doi.org/1 $0.1126 /$ science. 1096158.

17. Arpaia N, Godec J, Lau L, Sivick KE, McLaughlin LM, Jones MB, et al. TLR signaling is required for Salmonella typhimurium virulence. Cell. 2011;144(5): 675-88. https://doi.org/10.1016/j.cell.2011.01.031.

18. Doherty GJ, McMahon HT. Mechanisms of endocytosis. Annu Rev Biochem. 2009; 78(1):857-902. https:/doi.org/10.1146/annurev.biochem.78.081307.110540.

19. El-Sayed A, Harashima $\mathrm{H}$. Endocytosis of gene delivery vectors: from clathrin-dependent to lipid raft-mediated endocytosis. Mol Ther. 2013;21(6): 1118-30. https://doi.org/10.1038/mt.2013.54.

20. Parton RG, Del PM. Caveolae as plasma membrane sensors, protectors and organizers. Nat Rev Mol Cell Biol. 2013;14(2):98-112. https:/doi.org/10.1038/ nrm3512.

21. Li T, Qin K, Li N, Han C, Cao X. An endosomal LAPF is required for macrophage endocytosis and elimination of bacteria. P Natl Acad Sci USA. 2019;116(26):12958-63. https://doi.org/10.1073/pnas.1903896116.

22. Pascual-Lucas M, Fernandez-Lizarbe S, Montesinos J, Guerri C. LPS or ethanol triggers clathrin- and rafts/caveolae-dependent endocytosis of TLR4 in cortical astrocytes. J Neurochem. 2014;129(3):448-62. https://doi.org/1 $0.1111 /$ jnc. 12639 .

23. Williams TM, Lisanti MP. The caveolin proteins. Genome Biol. 2004;5(3):214 https://doi.org/10.1186/gb-2004-5-3-214

24. Feng H, Guo L, Song Z, Gao H, Wang D, Fu W, et al. Caveolin-1 protects against sepsis by modulating inflammatory response, alleviating bacterial burden, and suppressing thymocyte apoptosis. J Biol Chem. 2010;285(33): 25154-60. https://doi.org/10.1074/jbc.M110.116897.

25. Tsai TH, Chen SF, Huang TY, Tzeng CF, Chiang AS, Kou YR, et al. Impaired Cd14 and Cd36 expression, bacterial clearance, and Toll-like receptor 4Myd88 signaling in caveolin-1-deleted macrophages and mice. Shock. 2011; 35(1):92-9. https://doi.org/10.1097/SHK.0b013e3181ea45ca.

26. Minguet S, Kläsener K, Schaffer A, Fiala GJ, Osteso-lbánez T, Raute K, et al. Caveolin-1-dependent nanoscale organization of the $B C R$ regulates $B$ cell tolerance. Nat Immunol. 2017;18(10):1150-9. https://doi.org/10.1038/ni.3813.

27. Mitchell J, Kim SJ, Seelmann A, Veit B, Shepard B, Im E, et al. Src family kinase tyrosine phosphorylates Toll-like receptor 4 to dissociate MyD88 and $\mathrm{Mal} /$ Tirap, suppressing LPS-induced inflammatory responses. Biochem Pharmacol. 2018;147:119-27. https://doi.org/10.1016/j.bcp.2017.11.015.

28. Deng S, Wu Q, Yu K, Zhang Y, Yao Y, Li W, et al. Changes in the relative inflammatory responses in sheep cells overexpressing of Toll-like receptor 4 when stimulated with LPS. PLoS One. 2012;7(10):e47118. https://doi.org/1 0.1371/journal.pone.0047118. 
29. Bai H, Wang Z, Hu R, Kan T, Li Y, Zhang X, et al. A 90-day toxicology study of meat from genetically modified sheep overexpressing TLR4 in SpragueDawley rats. PLoS One. 2015;10(4):e121636. https://doi.org/10.1371/journal. pone.0121636.

30. Wei S, Yang D, Yang J, Zhang X, Zhang J, Fu J, et al. Overexpression of Tolllike receptor 4 enhances LPS-induced inflammatory response and inhibits Salmonella Typhimurium growth in ovine macrophages. Eur J Cell Biol. 2019;98(1):36-50. https://doi.org/10.1016/j.ejcb.2018.11.004.

31. Wang $S$, Cao Y, Deng S, Jiang X, Wang J, Zhang $X$, et al. Overexpression of Toll-like receptor 4-linked mitogen-activated protein kinase signaling contributes to internalization of Escherichia coli in sheep. Int J Biol Sci. 2018; 14(9):1022-32. https://doi.org/10.7150/ijbs.25275.

32. Geissmann F, Jung S, Littman DR. Blood monocytes consist of two principal subsets with distinct migratory properties. Immunity. 2003;19(1):71-82. https://doi.org/10.1016/s1074-7613(03)00174-2

33. Dunay IR, Damatta RA, Fux B, Presti R, Greco S, Colonna M, et al. Gr1(+) inflammatory monocytes are required for mucosal resistance to the pathogen toxoplasma gondii. Immunity. 2008;29(2):306-17. https://doi.org/1 0.1016/j.immuni.2008.05.019.

34. Serbina NV, Jia T, Hohl TM, Pamer EG. Monocyte-mediated defense against microbial pathogens. Annu Rev Immunol. 2008;26(1):421-52. https://doi. org/10.1146/annurev.immunol.26.021607.090326.

35. Lee JS, Jung ID, Lee CM, Park JW, Chun SH, Jeong SK, et al. Outer membrane protein a of Salmonella enterica serovar Typhimurium activates dendritic cells and enhances Th1 polarization. BMC Microbiol. 2010;10(1): 263. https://doi.org/10.1186/1471-2180-10-263.

36. Deng S, Yu K, Zhang B, Yao Y, Wang Z, Zhang J, et al. Toll-like receptor 4 promotes NO synthesis by upregulating $\mathrm{GCH}$ expression under oxidative stress conditions in sheep monocytes/macrophages. Oxidative Med Cell Longev. 2015;2015:1-11. https://doi.org/10.1155/2015/359315.

37. Miksa M, Komura H, Wu R, Shah KG, Wang P. A novel method to determine the engulfment of apoptotic cells by macrophages using pHrodo succinimidyl ester. J Immunol Methods. 2009;342(1-2):71-7. https://doi. org/10.1016/j.jim.2008.11.019.

38. Rodriguez NE, Gaur U, Wilson ME. Role of caveolae in Leishmania chagasi phagocytosis and intracellular survival in macrophages. Cell Microbiol. 2006; 8(7):1106-20. https://doi.org/10.1111/j.1462-5822.2006.00695.x.

39. Shin JS, Gao Z, Abraham SN. Involvement of cellular caveolae in bacterial entry into mast cells. Science. 2000;289(5480):785-8. https://doi.org/10.1126/ science.289.5480.785

40. Huotari J, Helenius A. Endosome maturation. EMBO J. 2011;30(17):3481-500. https://doi.org/10.1038/emboj.2011.286

41. Mort JS, Buttle DJ. Cathepsin b. Int J Bio chem Cell Biol. 1997;29(5):715-20. https://doi.org/10.1016/s1357-2725(96)00152-5.

42. Blum JS, Fiani ML, Stahl PD. Proteolytic cleavage of ricin a chain in endosomal vesicles. Evidence for the action of endosomal proteases at both neutral and acidic pH. J Biol Chem. 1991;266(33):22091-5. https://doi. org/10.1016/S0021-9258(18)54537-3.

43. Kawai T, Akira $\mathrm{S}$. The role of pattern-recognition receptors in innate immunity: update on Toll-like receptors. Nat Immunol. 2010;11(5):373-84. https://doi.org/10.1038/ni.1863.

44. Weiss DS, Raupach B, Takeda K, Akira S, Zychlinsky A. Toll-like receptors are temporally involved in host defense. J Immunol. 2004;172(7):4463-9. https:// doi.org/10.4049/jimmunol.172.7.4463.

45. Jilling T, Simon D, Lu J, Meng FJ, Li D, Schy R, et al. The roles of bacteria and TLR4 in rat and murine models of necrotizing enterocolitis. J Immunol. 2006;177(5):3273-82. https://doi.org/10.4049/jimmunol.177.5.3273.

46. Roy MF, Lariviere L, Wilkinson R, Tam M, Stevenson MM, Malo D. Incremental expression of Tru correlates with mouse resistance to Salmonella infection and fine regulation of relevant immune genes. Genes Immun. 2006;7(5):372-83. https://doi.org/10.1038/sj.gene.6364309.

47. Ghosh M, Subramani J, Rahman MM, Shapiro LH. CD13 restricts TLR4 endocytic signal transduction in inflammation. J Immunol. 2015;194(9): 4466-76. https://doi.org/10.4049/jimmunol.1403133.

48. Plociennikowska A, Hromada-Judycka A, Borzecka K, Kwiatkowska K. Cooperation of TLR4 and raft proteins in LPS-induced pro-inflammatory signaling. Cell Mol Life Sci. 2014;72(3):557-81. https://doi.org/10.1007/s0001 8-014-1762-5.

49. Kumari S, Mg S, Mayor S. Endocytosis unplugged: multiple ways to enter the cell. Cell Res. 2010;20(3):256-75. https://doi.org/10.1038/cr.2010.19.
50. Lajoie P, Nabi IR. Lipid rafts, caveolae, and their endocytosis. Int Rev Cell Mol Biol. 2010;282:135-63. https://doi.org/10.1016/S1937-6448(10)82003-9.

51. Mitchell G, Isberg RR. Innate immunity to intracellular pathogens: balancing microbial elimination and inflammation. Cell Host Microbe. 2017;22(2):166-75. https://doi.org/10.1016/j.chom.2017.07.005.

52. Yates RM, Hermetter A, Russell DG. The kinetics of phagosome maturation as a function of phagosome/lysosome fusion and acquisition of hydrolytic activity. Traffic. 2005;6(5):413-20. https://doi.org/10.1111/j.1600-0854.2005. 00284.x

53. Yates RM, Russell DG. Phagosome maturation proceeds independently of stimulation of Toll-like receptors 2 and 4. Immunity. 2005;23(4):409-17. https://doi.org/10.1016/j.immuni.2005.09.007

54. Sendler M, Maertin S, John D, Persike M, Weiss FU, Kruger B, et al. Cathepsin $\mathrm{b}$ activity initiates apoptosis via digestive protease activation in pancreatic acinar cells and experimental pancreatitis. J Biol Chem. 2016:291(28):14717-31. https://doi.org/10.1074/jbc.M116.718999.
Ready to submit your research? Choose BMC and benefit from:

- fast, convenient online submission

- thorough peer review by experienced researchers in your field

- rapid publication on acceptance

- support for research data, including large and complex data types

- gold Open Access which fosters wider collaboration and increased citations

- maximum visibility for your research: over 100M website views per year

At BMC, research is always in progress.

Learn more biomedcentral.com/submissions 